\title{
The Chinese Political Dissidents in Exile: Struggle for a Sustainable and Relevant Movement
}

\author{
Jie Chen \\ Political Science and International Relations, University of Western Australia, Perth, Australia \\ Email: jie.chen@uwa.edu.au
}

Received 9 December 2015; accepted 4 January 2016; published 7 January 2016

Copyright (C) 2016 by author and Scientific Research Publishing Inc.

This work is licensed under the Creative Commons Attribution International License (CC BY). http://creativecommons.org/licenses/by/4.0/

c) (i) Open Access

\begin{abstract}
The overseas Chinese democracy movement started in the early 1980s and comprised of the networks, organisations and campaigns of those mainland Chinese activists, in exile mostly in the West, particularly the United States. These dissidents were mainly Democracy Wall (1978-79) veterans, the Tiananmen Square event (1989) student leaders and intellectuals, and other activists who became politicised while studying or living abroad. This paper investigates the reflection and readjustment of the political exiles to halt the decline of their movement over the past decade, to make it more sustainable and relevant to both their host nations and conditions in China in the new century. While the movement has little direct role to play in China's democratization or its host states' policies towards China, the exile community has become more flexible and adaptable in both strategic direction and tactical approaches, with more efforts to: intervene and support new social contention in China, establish specialized campaign agencies, experiment with new models of organizational development, influence domestic and international public opinions, and rejuvenate solidarity with the evolving civil societies in Taiwan and Hong Kong on the basis of shared political values more than "one China" sentiment. The significance of these new dynamics, in terms of the movement's survival and impact, can only be appreciated by breaking free from state-centric perspectives which have already been challenged in the literature on transnational social movements and exile politics.
\end{abstract}

\section{Keywords}

Overseas Chinese Democracy Movement, Dissidents, Exile Politics, Tiananmen Event, Civil Society

\section{Introduction}

The overseas Chinese democracy movement (OCDM) started in the 1980s and consisted of the networks, orga- 
nisations and campaigns of those mainland Chinese activists, in exile mostly in the West, particularly in the United States (US). These dissidents were mainly Democracy Wall (1978-79) veterans, the Tiananmen Square event (1989) student leaders and intellectuals, and other activists who became politicised while studying or living abroad. Through lobbying, publicity, conferencing, training, protests and many other contentious activities, they advocate liberal democratic values to systematically expose the fundamental flaws in the system of the party-state in China and struggle for its ending.

Based on primary sources and field research, this paper investigates the struggle of the Chinese political dissidents in exile to arrest their declining movement, to make it more sustainable and relevant to both their host nations and democratization of China in the new century. First, the paper presents the historical context and accounts for the wax and wane of OCDM. Second, it offers a general analysis of the reflection and tactical readjustment on the part of the democracy activists under the more challenging circumstances. In the subsequent sections, the paper examines the discernible efforts or trends emanating from the movement which are related and mutually reinforcing, epitomizing a new direction of the movement. They include attempts to: intervene in the Rights Defending Movement within China; extend financial and spiritual support fordomestic activists; undertake new experiment in organizational development; adopt more diverse and creative ways to influence public opinion; and rejuvenate solidarity with the other societies of Greater China, particularly Taiwan. The conclusion sheds broad light on whither the movement goes in light of these new trends.

\section{Wax and Wane of the Movement}

Inspired by the suppressed Democracy Wall Movement in Beijing (1978-79), Wang Bingzhang, a medical graduate of McGill University (Canada), initiated in New York in December 1983 the Chinese Alliance for Democracy (CAD), the first overseas political opposition organization of mainland Chinese background since 1949. This single spark was followed by a prairie fire from June 1989, when the exodus of Tiananmen students and intellectuals, and agitation caused by the Beijing crackdown, led to a climax of political activism in the Chinese diaspora communities worldwide. These new comers to the OCDM scene founded the Federation for a Democratic China (FDC) in Paris in September 1989, which subsequently established branches in 25 countries, boasting 3000 members. CAD also expanded, reaching a similar number of members and setting up branches in dozens of countries well beyond North America by the end of 1989, while maintaining secret contact points inside China. By the early 1990s, there emerged a robust global sphere of overseas Chinese dissident politics. Their active networking, campaigning and lobbying penetrated Chinatowns and university campuses, and interacted with the Western governments, parliaments, international media and social groups. However, from the late 1990s, the movement started to lose its momentum, stagnating and declining in its visibility and influence, even though between 50 and 60 new organizations had been formed (Chen, 2014: pp. 446-448). Shrinking rank and file of the established OCDM groups was particularly observable. Xue (2013), the CAD president (2011-15), estimated the remaining membership of the organization as around 200 (2013). Sheng (2013), the current FDC president, believed her organization still retained about 100 active members. Other indicators of the movement's low tide were the much smaller turnout at conferences and protest rallies, financial difficulties, deteriorating reputation of the organizations and activists, and abandoning of the cause by some well-known activists in favour of careers in business, academia and religion (Zhou, 2010: p. 78).

The downward trajectory was caused by a conjunction of structural circumstances and problematic agency. The international environment started to become more arduous for the movement from the mid-1990s. The Western nations started to abandon their Tiananmen sanctions against China. The new century has seen the OCDM fighting even more of an uphill battle. China's international economic and diplomatic prowess continued to grow, forging strategic partnerships with major Western powers. China's indispensable roles in a host of newly salient global economic, environmental and security issues, such as transnation alterrorism, financial stability, Korean nuclear crisis, and climate change, made the Western nations more muted on the country's human rights record (He, 2013). Meanwhile, political transformation in Taiwan weakened the movement. Before democratisation of its own authoritarian political system which started from the late 1980s, the Republic of China (ROC) on Taiwan functioned as an ideological rival to the People's Republic on the mainland and treated Wang and his followers as honourable anti-communist warriors. During the 1980s-90s, the Kuomintang regime in Taipei was the biggest financial sponsor of the movement. Enthusiasm started to dwindle from the late 1990s, due to political de-Sinification, cross-straits rapprochement and Taipei's attempt to capitalize on China's phe- 
nomenal economic growth. Another cooling effect on OCDM arose from the changing political dynamics in the Chinese diaspora communities in the West. More and more migrants and students have changed their attitude towards Beijing, from universal condemnation or shunning of the regime due to its political repression to embracing it, for the sake of economic and career benefit, or as a result of Beijing's success in its soft power campaigns in Chinatowns worldwide. Diasporic attraction to the homeland has also been encouraged by Beijing's own united front initiatives which include offering business and employment opportunities, and organizing tour groups, targeting both the students abroad and the diaspora community at large. ${ }^{1}$ Marginalization of the political exiles in the overseas Chinese communities significantly weakened their grassroots support base. It must be further noted that the Chinese government's perfection of its border control policy has exacerbated the overseas activists' attempt to develop opposition cells within China. They have been banned from visiting China and the post-handover Hong Kong. For those Democracy Wall veterans and Tiananmen student leaders and intellectuals, they typically have never been able to visit China ever since they left the country, irrespective of their residential status abroad including foreign citizenship, and regardless of the circumstances in which they left the country. In the exile community, a popular saying is that while they have found a haven of freedom under foreign skies, they have lost the land of China, or "gaining the sky, losing the ground". Some adventurous exile dissidents tried to sneak into China, only to be seized upon landing, followed by interrogation and expelling.

Evolution of OCDM reflects the interaction between the changing structural environment and the activists' agency. In the discourse of transnational social movements, the roles of social activists or political entrepreneurs are posited as among the crucial factors which condition the movements' effective development. The significance of "actor characteristics" is such that activists with effective transcultural communication and campaign skills, and dense exchanges and close solidarity between the various organizations, are among the enabling elements for the movements (Keck \& Sikkink, 1998: pp. 28-29). In OCDM, over the years prominent roles were played by former beneficiaries of the party-state (such as Chen Yizhi, and Wan Runnan), or Democracy Wall veterans (such as Wei Jingsheng, Xu Wenli, and Wang Xizhe), or the 1989 student heroes from the Tiananmen Square such as Wuer Kaixi, Wang Dan and Liu Gang, or the emerging professional lobbyist-kind of activists who first came to the US to study or migrate but successfully recreated themselves as formidable activists (such as Yang Jianli and Fu Xiqiu). These democracy activists have different styles and knowledges which complemented each other, though many older ones do not have the sort of effective transcultural communication and campaign skills. What became debilitating for the movement was the dearth of another enabling element mentioned in the theory, namely comradely solidarity. For many years from the mid-1990s, the movement was plagued by chronic infighting and factionalism within and between dissident organizations. There was little dispute over fundamental political ideals, and hostilities were chiefly caused by clashing egos of the activists, self-interests and allegations of corruption. Rowena He (2013), a Harvard researcher of Tiananmen event, argued that the splits, infighting, and inter-personal bitterness within the community of exiled dissidents arose partially from their domestic political socialization experiences in China that focused on struggles against nature and the people, rather than conflict resolution and leadership. Another debilitating factor she suggested was the traumas suffered by the dissidents before leaving China, claiming that she "observed signs and behaviour of post-traumatic stress disorder among almost every single exiled dissident whom I have encountered over the years, in both their personal and public lives” (2014, p. 175). Wang Dan (2012: p. 348), a renowned Tiananmen student leader now in exile, also attributed the infighting mainly to the beliefs, values and attitudes adopted by the activists in their early political education. He candidly admitted that while they had embarked on a pro-democracy path, many exile activists including himself had hardly shaken off all the legacies of the communist political culture which heavily influenced their formative years. Thus they saw the political world in black-or-white fashion, treating fellow travellers with different opinions as enemies, and were unable to use defined procedures and civil dialogue to settle conflicts. Thus different opinions often led to attacks and split. This trend was compounded by a ubiquitous fear of Beijing's infiltration through an increasing number of informants and agents, which often caused mutual suspicion among some activists. Yan Jiaqi, the first president of FDC and a well-learned political scientist, said that factionalism and infighting were normal in the ranks of political activism in exile, and that the overseas dissident movements from the Soviet Union and Eastern Europe, and even the Solidarity movement within Poland, were no exceptions either (Yan, 2008). This may well be true-and one can also cite the bitter infighting and split in the overseas movements of the much earlier Russian Bolsheviks and Sun Yat-sen's republi-

${ }^{1}$ For President Xi Jinping's recent speech on patriotic united front, see Xi (2015). 
can revolution, it is undeniable that the phenomenon had caused reputational harm to OCDM, enduring personal tension among some of the leading activists, and disillusionment among the Western and Taiwanese supporters and funders. The problematic agency and a worsening structural environment mentioned earlier became mutually reinforcing to cause the movement to lose its momentum.

Today even the most dedicated OCDM veterans would not deny that the movement has overall declined compared to its climax reached during the immediate post-Tiananmen years. ${ }^{2}$ However, the history of OCDM is not a story of total disarray. New developments have been emerging and become salient during the recent decade, demonstrating a trend of reflection and adaptation of the activists in reaction to the arduous political environment and debilitating impacts caused by the intra-movement problems. Consequently, the movement appears to have gained a new lease of life by becoming organizationally and tactically more diverse, creative and society-oriented, as discussed in the following sections.

\section{Assessment, Reflection and Readjustment}

A balanced and broad analytical framework is necessary to appreciate the meaning of the new trends. In the more vocal negative commentaries of the OCDM since the $20^{\text {th }}$ anniversary of the Tiananmen event, the naysayers mostly single out the movement's declining impact on the China policies of the host states and China's own political development. An editorial in the Beijing-based Global Times claims that overseas democracy activists used to be confident in the overthrow of the Chinese political system but have now become marginalized in the West-China diplomatic chessboard. In fact they have become the smallest pieces in the board with negligible influence over the Western states' policies towards China (Chan, 2013). This official line is shared by a veteran CNN correspondent who covered the Tiananmen event and China's international relations. He believes that OCDM was influential in the 1990s, when the exile dissidents effectively used the Congressional debate to present their proposals to force changes in China as a condition to retain its most favoured nation (MFN) status and secure permanent normal trade relations (PNTR) with the US. Activists also benefited from the role of the then Assistant Secretary of State Winston Lord (1993-1997), who emphasized human rights due to his personal engagement with the student activists at Beijing University during his ambassadorial time in China (1985-89). However, the Clinton administration's decision to delink the annual decision-making on China's MFN status from its human rights record in 1995, and grant PNTR to China in 1999, deprived the dissidents of key campaign leverages. It is further argued that exile dissidents today are manipulated by the Western political forces for their own domestic politicking despite the more consistent support from a few politicians like Nancy Pelosi (the Democratic Leader of the US House of Representatives), caught in an American debate, not China's. ${ }^{3}$ Dismissing the significance of OCDM, a former Asia policy adviser to President Obama simply said that dissidents in exile needed to be someone like Kim Dae-jung, who already had his own popular powerbase in the homeland (South Korea) before exile in the US (1982-85), so that Washington could find them more usable for its own geopolitical goals. ${ }^{4}$ None of the exile Chinese dissidents was ever a major figure in the national politics. Nor has any become an undisputed leader in the overseas Chinese communities. Such critiques, however, are state-centric. Based on numerous case studies, Goddeer concludes that activities undertaken in exile politics are multifaceted, and its objectives and efficacy must be judged accordingly. Three fields are highlighted: the changing of policy (in both the home and the host land), the informing and influencing of public opinion, and the development of new ideas (Goddeeris, 2007: p. 397, 402).

To influence and change state policies remains important to the dissidents and they are making greater efforts. For example, regular testimonies at the US Congressional hearings are characterized by more professional presentations on diverse issues including one-child policy as well as other human rights and democracy issues. Dialogue with the Canadian foreign policy officials has been held once or twice a year, though such engagement with the Australian parliament has become sporadic. At the meetings of the United Nations Human Rights Council (UNHRC) in Geneva in 2013-14, activists expressed sharply critical views in the scrutiny of China's Universal Periodic Review report and its bidding for the council's membership (Friends of FDC, 2014-15). Wei Jingsheng, chairman of the Overseas Chinese Democracy Coalition and an old hand in the Congressional and UN lobbying, maintains his optimism, arguing that even in the post-PNTR Congress, there are still opportunities to

\footnotetext{
${ }^{2}$ See, for example, Chen (2013). Chen serves as the vice president of CAD and chief editor of Beijing Spring.

${ }^{3}$ Personal interview, August 2014, Perth, Australia. Interviewee wishes to remain anonymous.

${ }^{4}$ Personal interview, December 2014, Perth, Australia. Interviewee wishes to remain anonymous.
} 
influence for the pro-active dissidents like himself. He has claimed that in her meeting with him in late September 2015, Pelosi said that when she met President Xi Jinping a few days earlier, she considered Wei's opinions and thus did not mince her words in criticizing China's human rights abuses. Wei (2015) believes that in a relationship of mutual use with the Western politicians, the dissidents' cause can be advanced.

It has become much harder, however, for the dissidents to influence the US administration and Western governments in general due to the changing strategic environment mentioned earlier. Those naysayers' assessments of OCDM's position are not far from the mark. As Wei himself has admitted, the UN Commission on Human Rights (predecessor of UNHRC) used to function as a key forum where member states frequently debated and condemned China's political repression. Exile dissidents enjoyed the opportunities to unnerve the Chinese delegates by attempting to mobilise votes to pass resolutions aimed at investigating human rights conditions in China. However, when the Commission was transformed to UNHRC in 2006, Beijing had already commanded sophisticated maneuvering tactics to stave off the forum's diplomatic pressure. Dissidents may still use the Council's periodical China review and annual meetings to expose the rights abuses and make moral appeals, but can no longer realistically contemplate the tactic of vote mobilisation to pressurize China (Wei, 2014).

Goddeeris' positive view of the efficacy of the exiles' campaigns to change state policies is in fact based on the study of states much smaller than China, including the East European states and Cuba. He also includes the better-resourced governments in exile as well as exile political movements. Challenges confronting the Chinese activists are substantially more arduous. This point can be more poignantly made by looking at China's own region, where exile activists from South Korea, Taiwan and the Philippines during the 1970s-80s benefited from the fact that the US administration and Congress had far more influence over their home states than Washington has ever had over Beijing. This ensured the relative effectiveness of their lobbying work.

The Chinese dissident circles seem to be encouraged by the recent talks in the foreign policy communities in the US and some of its Asian allies suggesting a major readjustment of their relations with China. China's aggressive behaviour in territorial disputes in East and South China Seas, and the escalating cyber hacking reportedly conducted from the country, may cause high tension with the West. However, if the dissidents assume that this may escalate into a Cold War-kind of containment of China so that they would receive substantial support from the West, their minds should be more measured. In an era characterised by comprehensive economic, financial and social integration between the West and China, it is anyone's guess whether the US and its allies would be interested in a strategy of across-the-board rivalry.

Still, Goddeeris' idea of dissidents' multifaceted activities and impacts point to useful benchmarks beyond the state realm. This idea is more elaborately presented in Wapner's (1996: pp. 1-16) theorization of world civic politics, which opens up a new horizon in assessing the scope and impacts of transnational activism. It argues that the notion of political influence should be broadened so that in addition to their work on the policies of states, the impact of transnational social movements must be assessed from a different but related dimension, namely the attempt by activists to create or manipulate shifts in public opinion and shape the conduct of behaviour by working directly within and across national societies. By disseminating new ideas and information through awareness-raising programs towards the general public, enlivening public debates, and cooperating with and influencing other non-state actors, transnational activists attempt to lead the society to change independently of state policies. Though civic politics may eventually lead to a change in state policies, this may not be the goal or immediate objective of activists. Wapner's idea is grounded on the work of large international environmental NGOs such as Greenpeace and World Wildlife Fund, which enjoy UN consultative status and operate their own offices inside China. Since they have encountered frustrations in trying to influence China's policies and the UN's approaches towards China on the issues of conservation and environmental protection, hence the necessity to also assess their work from the perspective of civic politics, ${ }^{5}$ it is then only natural that the exile dissidents, who target China on the core political issues without the slightest chance to set up branches in China, should not be belittled due to an apparent lack of influence over the party-state, or any other state for that matter.

Ideas of Goddeeris and Wapner are capitalized on in this investigation of the OCDM's intensified activities beyond the state policy arena in the recent decade. Their ideas, however, only serve as a broad guide to organize my empirical observations of the OCDM's proliferating strands of activism, beyond a narrow focus on the dissidents' interactions with, and impacts on, the state. This borrowing in broad sense is because the complex Chinese exile movement is not the sort of cases used in Goddeeris' generalization. Also, as a diaspora-based trans-

${ }^{5}$ For an elaborate analysis of transnational environment movements and China, see Chen (2012). 
national movement which is focused on one country, the OCDM is different from the typical transnational social movement analysed by Wapner which comprises of cause-oriented international groups with multinational membership.

First, one must discern any influence on public sentiment from the dissidents' activities in the state policy arena. Lobbying campaigns at the various parliaments, and the shaming and exposing of Beijing at the UN agencies, may not sway state policies, but the wide media publicity thus generated may influence public opinion. ${ }^{6}$ Second, and more importantly, due analytical weight must be given to the kind of OCDM activities which are of general developmental nature or mainly target at the society and public opinion both inside and outside China. The overall deteriorating operational environment at the state and diaspora levels, and the rise of new social contention in China such as the Rights Defending Movement, have forced the exile activists to soulsearching, reflection, and readjustment over the past decade. If they were ever trying to ready themselves to change or even take over the political regime in China, only to find their revolutionary bubble burst in the 1990s, they have now become more nuanced and practical. The new consensus is that the movement must be prepared for a long-term, more effective and sustainable struggle, making itself more geared towards China's complex process of democratization and the Western and Taiwanese socio-political reality. Niche roles must be identified, with a closer focus on the sort of activities which their fellow travellers inside China cannot undertake, rather than lamenting at their own perennial exile. ${ }^{7}$ As a result, the OCDM organizations have started to strengthen the activities aimed at sustaining the morale of domestic social activists and enhancing their campaigns, swaying the public opinion of the realities of China, preserving and cultivating fresh activist resources, and capitalizing on new political awakening in the mature civil societies in Taiwan and Hong Kong. More use has been made of online platforms and social media (including the China-based Weibo and We Chat) to mitigate the debilitating effects of decreased organizational membership. Though perennial exile has weakened the overseas activists' personal touch of socio-political transformation in China, dense connections with domestic activists and the use of advanced technology ensure that they can easily receive accurate information from China and determinate it quickly and widely, against the odds posed by China's internet blocking devices. ${ }^{8}$ Generally the OCDM activities have become more creative and diverse, showing new dynamics as reflected in the endeavours presented in the following sections.

These developing trends have coincided with much decreased incidents of infighting within the movement, another result of lesson-learning as well as fatigue. Reconciliation or ceasefire is epitomized, for example, by the regular meetings of an Overseas Coordinating Committee of the Chinese Democracy Movement which was formed in 1999 to coordinate commemoration of the $20^{\text {th }}$ anniversary of the Tiananmen event. Initiated by 15 organizations, it now boasts a membership of more than 50 . Although this has by no means filled the cracks and resolved personal bitterness caused by factional infighting, the Committee functions like a looser UN of the movement. It has become a forum to synchronize the global Tiananmen commemorations through web-based conferences and discuss general issues of the movement (Xue, 2015). Meanwhile, in 2012, to celebrate the $30^{\text {th }}$ anniversary of China Spring magazine, the predecessor of CAD, many activists joined to release a Convention of Overseas Chinese Democracy Movement

(http://news.boxun.com/news/gb/party/2012/06/201206080254.shtml\#.UOg-WXfYGSo) which calls for comradely solidarity and mutual respect.

\section{Support for Domestic Socio-Political Contention}

Supporting and instigating political opposition within China has been the OCDM's imbedded duty. However, activists have met mounting practical difficulties. In China, attempts to establish political parties (such as China Liberal Democratic Party in 1992, and China Democracy Party in 1998), and dissidents calling for explicit systemic reform of the party-state (such as Charter 08 movement), have been severely punished with long jail terms. Also, to liaise and collaborate with such revolutionary elements inside China would often necessitate clandestine visits to the country by the exile dissidents, an act which has become infeasible and risky, as shown in the jailing or expelling of a number of dissidents who sneaked into the country by using pseudonyms. On the other hand,

\footnotetext{
${ }^{6}$ For a typical opinion piece penned by dissidents on China's role in UNHRC, see Yang (2013). Yang is the founder and president of the Washington DC-based Initiatives for China.

${ }^{7}$ This summary of the emerging consensus among the leading dissidents is based on personal interviews in Germany, the US, and Australia, 2014-15. See also Wang (2011).

${ }^{8}$ For an earlier discussion of the role of internet in transnational activism, see Yang (2009: pp. 185-208).
} 
OCDM could become irrelevant if the leading dissidents overseas were stuck to their Tiananmen or Democracy Wall idealism. China marched forward in their exile years, with new social cleavages and new waves of protest movements developing over the past decade. Spearheaded by rights lawyers, the so-called Rights Defending Movement has operated within China's existing legal and political mechanisms and tried to use them to defend citizens' rights in the issue fields of low politics, including food safety, land acquisition, environmental protection, housing affordability, educational opportunities, factory workers' rights and conditions, and gender equality. The authorities' tolerance started to become thinner since 2013 after some rights lawyers tried to initiate a New Citizens Movement, a platform trying to steer the Rights Defending Movement to a clearer advocacy for civil society, constitutional rights, rule of law and public declaration of the national leaders' private property. However, while the Xi Jinping administration started a nationwide crackdown on rights lawyers in mid-2015, overall the Rights Defending Movement has been more feasible and effective in organization and mobilization under the current political circumstances in China, than outright attempts to stage real political opposition.

Dissidents in exile saw the new socio-political contention as opening a fresh window for their own struggle and broadened their domestic focus. Their task has become to disseminate to China the international experiences of non-violent social movements and strive to ideationally connect the Rights Defending Movement to the track of struggle for democracy. Supporting this movement also helps in broadening the dissidents' united front with transnational human rights movements. At a time when exile politics has become a rarity in the world, OCDM can only realistically forge solidarity with transnational activists whose concern with China are mostly based on a rights frame, not wholesale regime change. This tactical moderation also makes the OCDM more acceptable to the Western funding bodies which often do not like to jeopardize their governments' China engagement policies by funding radical exile groups.

The OCDM organizations' engagement in the Rights Defending Movement is characterized by a strenuous effort to internationalize the struggle, such as bringing out the activists for protest rallies in the UN or for training sessions overseas. What's particularly revealing of this new momentum of OCDM is that some former Tiananmen heroes in exile have moderated their political tones by pursuing more modest and feasible programs. For example, Chai Ling, the chief commander of a Tiananmen Square Protection Headquarters of 1989, founded All Girls Allowed in 2010 to campaign on the wellbeing of rural women and injustices in family planning. Han Dongfang, the founder of Beijing Workers Autonomous Union in 1989, has moved on to promote a collective bargaining mechanism to improve the rights and working conditions of the Chinese workers within the official trade union system (Boxun News, 2013b). Even Wei Jingsheng, the veteran democracy fighter known to be radical, has also started to advocate the Chinese workers' collective bargaining rights, claiming that this would raise workers' income, thus expanding the Chinese market for the benefit of both its own economy and Western business (Wei Jingsheng Foundation, 2015).

Reflecting the above trend, extending more tangible financial and spiritual support to domestic activists has become a distinct sector in OCDM. The number of participating organizations has increased, including some whose mandate is to specifically provide such support. Also, recipients in China are no longer just traditional political dissidents, but increasingly also rights lawyers. For many years, China Spring (and its successor magazine Beijing Spring), was the main financial supporter for domestc fellow travellers through honorarium. Other groups started their own systematic financial support for the victims of political persecutionin more recent years, including FDC's “ten dollar humanitarian donation program” (initiated in 2004). More significantly, new support groups have emerged, created by those dissidents who stayed out of scandolous factional in fighting which besieged the larger OCDM groups, thus attracting more donors. For example, Zhou Fengsuo, a leader of the 1989 Student Congress in Beijing, established Humanitarian China in San Francesco in 2007. The organization provided financial support to around 100 prisoners of conscience and their families in dire financial stress in 2014 alone, including more than US\$10,000 to the family of Ilham Tohti, a Uighur scholar jailed for life for criticizing Beijing's policy towards minorities (CK, 2015a). Sun Liyong, a former police officer in Beijing who spent seven years in jail due to hisrole in Tiananmen movement, now heads the Sydney-based Support Network for the Persecuted in China, which he founded in 2005 to provide financial assistance to the families of those jailed for their political or religious beliefs, ranging from US\$600 to US $\$ 1,000$ in each case. Sun (2015) vividly spoke of the morale boosting effect of this work, arguing that cash aid to the families of those frontline dissidents helped the wives to meet their jailed husbands, enabled their children to go to school, and improved the quality of the prisoners' meals. International humanitarian assistance made the wives, children and parents of the jailed democracy fighters regard them as heroes, and made the heroes feel that they were far from isolated. As- 
sistance in the overseas settlement of the domestic activists and their families is another humanitarian endeavour of the OCDM groups. Such activities include offering cash and accommodation to the new arrivals in the US, and the more complex operation to secure a transit to a Western country of the Chinese activists who have escaped to Thailand, a key escape route after Hong Kong's handover to China. This operation includes helping the escapees to apply for refugee status from the Bangkok office of The UN High Commissioner for Refugees (UNHCR) and avoid harassment by the Thai authorities. ${ }^{9}$

Activists languishing in jailal so have their morale boosted by the awards they receive, some of which also include cash. Throughout the 1980s-90s, a Chinese Democratic Education Foundation based in San Fancesco was the only institution giving such awards. It was started by some former Rightists who eventually settled in the US, and the awardees included democracy activists from Taiwan, Hong Kong as well as the mainland China. With a former Tiananmen activist Fang Zheng as its president, the foundation has focused on Chinese dissidents, intellectuals and rights lawyers over the past decade (http://www.cdef.org/). Meanwhile, the practice of giving awards and prizes to domestic dissidents and rights lawyers has become a major pursuit of the OCDM at large. The proliferating awards, their founders and starting years include: China Youth Human Rights Award (Wang Dan and other Tiananmen student leaders, 2001), Free Spirit Award (Independent Federation of Chinese Students and Scholars, 2001), Wei Jingsheng Chinese Democracy Champion Prize (The Wei Jingsheng Foundation, 2004), Human Rights Fighter Award (Asia-Pacific Human Rights Foundation, 2005), Freedom Pioneer Award (Beijing Spring, 2007), Make a Better China Award (The Qi’s Cultural Foundation, 2008), Oskar Award for Chinese Freedom and Human Rights (a group of US-based dissidents, 2014), and Citizen Power Award (Initiatives for China, 2015). From their own experiences in China, those exile activists like Wei Jingsheng, who won the Olaf Palmer Prize in 1994, understand that such glory is important to keep up the spirit of the jailed dissidents and rights defenders.

\section{New Experiments in Organizational Development}

This dynamic is manifested by the formation of new kind of dissident organizations and fresh trials in the organizational development of some traditional membership-based groups. This diversification is not exactly a synonym for "multi-mountainism", a usual negative reference to the split and tension in the dissident camps. It is more about tactics to suit changing circumstances and self-conscious pursuit of emerging activists to find their special positions.

Apart from some of the aforementioned organizations specializing in financial support and award giving, professional lobbyist agencies have also emerged in the OCDM. These agencies, such as Initiatives for China (founded 2007), and China Aid (2002), were formed by activists who were disillusioned with the inefficacy and decline of the traditional groups, and sought to find their own niche roles in the movement. They tend to adopt creative approaches in their campaigns. For example, they recruited daughters of several Chinese prisoners of conscience to testify before the US Congress and speak at the UN, hence a human touch in their advocacy (Hiatt, 2013a). Meanwhile, specialized democracy training institutions have sprung up, including Civil Society Institute (Las Vegas, 2015), China Democracy School (Melbourne, 2011), New School for Democracy (Taipei, 2011), and the Tiananmen University of Democracy (San Francesco, 2014). The last two online universities were the initiatives of former protest leaders in Tiananmen Square. The New School for Democracy, which has Wang Dan as chairman of the board of directors, and Wang Juntao, a board member, offers courses in both political theories and practical operations such as knowledge and skills of working through the UN human rights mechanisms (http://idemocracy.asia/) The Tiananmen University of Democracy, headed by Feng Congde, is a resumption of a similar institution established on the Tiananmen Square shortly before the massacre in 1989. It is now offering courses taught by the renowned democratization scholar Larry Diamond. While enrolments for the courses in Wang's school are mostly from Taiwan and the mainland, the overwhelming majority of attendants at Feng's are mainland Chinese youth who manage to overcome the official internet blocking system (CK, 2015b).

New momentum in organizational rejuvenation is also seen in some traditional membership-based OCDM groups, with their often controversial approaches to recruit members and raise funding. Their focus is to capitalize on an increasing large number of Chinese visitors, students and even illegal migrants over the past ten years who seek permanent residence in a Western country, particularly the US, by applying for political refugee status.

\footnotetext{
${ }^{9}$ The arrest and deportation in November 2015 of two Chinese dissidents, Jiang Yefei and Dong Guangping, who had already been granted refugee status by UNHCR (Holmes, 2015), suggests that as a transit stop, Thailand's position has become more ambiguous.
} 
Joining an OCDM organization and participating in its activities would enhance such application. This offers lucrative "refugee business" opportunities to the cash-strapped and membership-depleted organizations which nonetheless can provide legal and political assistance. This practice has been spearheaded by the various China Democracy Parties (CDP). After the original CDP was crushed in China in 1998, hundreds of activists and members were arrested and received long-term imprisonment, with a combined time in prison totaling a thousand years (Yan, 2010). The harsh treatment of these daring dissidents created a unique moral aura for CDP, and association with this party might help a Chinese visitor, student or illegal migrant boost their chance to apply for the US green card on the ground of fear of persecution once returning home. Subsequently no less than four CDPs were set up overseas, all headquartered in New York, each claiming to be the legitimate inheritor of the original, competing against each other in "refugee business" by using the CDP brand. This practice has caused much controversy, regarding the perceived opportunism of both new members and their helpers, fraudulent dealings and profiteering. However, it is also true that under the current circumstances, this approach has served a number of useful purposes. It has brought in some fresh and younger members for the parties, increased the attendants of protest rallies, and helped cover the expenses of activities. Irrespective of the motivations of those who have joined a dissident organization and paid large sum of fees for assistance to achieve political credentials to boost their refugee status claim, they must go through the required systematic educational and training programs on democracy, with lectures given by bona fide dissidents including the real CDP founders in exile, and participate in various protest rallies. Even though new party members may disappear as soon as they receive permanent residential status of the US, this does not happen en masse as in the mid-1990s, when some Western governments' mass granting of permanent residence to all Chinese students and visitors who left China before Tiananmen event or shortly afterwards led to an instant evaporation of large number of members and followers of the major OCDM groups. Under the current circumstances, refugee status processing is based on individual cases, and some party members, particularly those who do have earlier experiences of political persecution in China, have stayed on in the parties. The National Committee of Democratic Party of China, founded in 2010 as the newest variant of CDP, has made good use of its new recruits to contribute to the cause. One of its regular activities is that each week the chairman Wang Juntao, a veteran dissident and one of the "black hands" accused of organizing the Tiananmen Square demonstrations, has been taking around 20 new members (mostly young Chinese students) to stage a protest rally in the Times Square in New York. The themes are focused on particular events in China such as jailing of a rights lawyer or crackdown on a mass rally. All participating members in this program, or "Jasmine Revolution" as officially called by the party, would make speeches in public expressing their understanding of the relevant events and condemning the Chinese government. While such activities may be part of an attempt to boost their chances with a US green card, the participants do feel exercised in a democratic process. A special feat is that, of the ten Chinese students abroad who released a declaration in May 2015 condemning the Tiananmen massacre, seven came from Wang's party, having learned crucial facts from those Tiananmen survivors in exile. This was the first time such a public statement was made by elements of the 1980s-90s generations who were the main carriers of the officially imposed culture of Tiananmen amnesia. Wang's affinitive and charismatic personality, and his prioritizing of personal connections and infrastructural development over political idealism in party-building, seems to open up a new path for traditional membership-based groups. Boasting a membership of 560, the party had donated a total of US\$52,700 to domestic activists by $2014 .^{10}$

\section{More Diverse and Creative Ways to Influence Public Opinion}

To influence public opinion, targeting both the international audiences and overseas and domestic Chinese communities, remains a major mission of OCDM. It is not only about challenging the state narrative of key historical events in the Chinese political history and propagating a democratic vision for the country, but also providing alternative information and opinions of the current political affairs in China, including events in Tibet and Xinjiang. Activists' endeavours in that regard have become more diverse and creative in recent years. Importance of their voice, expressed in various ways as elaborated in the following, can be read from a broad context where Beijing's propaganda machine has rapidly infiltrated the international community in recent years, with

\footnotetext{
${ }^{10}$ This discussion of Wang (2014) and activities of his party is based on personal interviews and on-site observation, New York, December 2014, and email from Wang (2015).
} 
news and commentary produced in Beijing rebroadcast through overseas Chinese print media and community radio stations that have been bought up, and through foreign language news services established by Beijing itself (Fitzgerald, 2014; Shambaugh, 2015).

Leading dissidents have maintained their vigour in awareness-raising campaigns at the general community level through speech tours of various institutions including universities and schools. In fact, as a result of advancement in study and career, some members of the exile community have become established academics in Western universities, thus occupying crucial positions to shape the perceptions of their students regarding the Chinese politics and host states' policies towards China. Meanwhile, more activists have appeared in the Chinese language programs and websites of major international broadcasting corporations, particularly Voice of America (both radio and television), Radio Free Asia, Deutsche Welle, Radio France, and the Falun Gong's print media and television channel, by way of regular colums and interviews. Interactive platforms often feature robust dialogue between the activists and readers and calling-in listeners based in China. Furthermore, opinion pieces penned by dissidents have regularly appeared in the mainstream media outlets such as The New York Times, The Washington Post, and The Wall Street Journal. This is partly because veterans like Wei Jingsheng are considered by the media as indispensable commentators on some political events in China, and partly because the new generation, English-fluent and lobbying-oriented activists are more media savvy.

Publication of books from the dissident community has become more diverse and mature. Thus apart from memoirs of those renowned Tiananmen heroes, which often celebrate their own historic roles, an increasing number of recent books are authored by lesser-known activists who want to tell their suffering in the hands and jails of the Chinese party-state. These more ordinary stories are often more appealing and contagious to the readers who can easily identify with the authors' experiences due to their own lived experiences in China or their parents', hence a more significant impact from the books. For example, Qi $(2010,2011,2014)$ a woman from Sichuang, has published three books detailing her ten years in labour campus in the 1960s-70s due to the crime of "counter-revolution", her experience of living like a dog after release caused by under-employment and poverty, and her crime's impacts on her parents and siblings. In her book, Sun (2011), a woman from Shanghai, tells the story of her three-year imprisonment due to her activities in support of Beijing students in June 1989, social estrangement and official harrassment after release, and the resultant misery in everyday family life. The afore mentioned Sun (2009), who supported the Tiananmen student movement as a policeman in Beijing, has presented a vivid human account of political prisoners, common prisoners and prison officers based on his own seven years inprison in the 1990s. The human story of political dissent is also told by Fred Hiatt, the editorial page editor of The Washington Post. With the arrangement by Initiatives for China, Hiatt came to know Ti-Anna Wang, the daughter of Wang Bingzhang, founder of CAD. Because of his frustration with the declining international support for OCDM, Wang started to talk and write loosely about the need of violent revolution. In June 2002, he was kidnapped in Vietnam-China border and abducted to China, in a joint operation of the two governments' agents. He was sentenced to life imprisonment in February 2003, under the charges of "terrorism" and "espionage". Targeting the middle-school-aged readers, Hiatt' (2013b) spart fiction is based on Ti-Anna's personal struggle to rescue her father.

Street protest activities remain a major method to sway public perceptions, and new tactics have been emerging. One is Operation Sparrow, a campaign launched by Initiatives for China which seeks to create international spotlight on the practice of forced eviction and land grabbing perpetrated mainly by the local governments in China for commercial redevelopment. The operation exposes to the international community the numerous cases of violent demolition of citizens' houses and acquisition of farmers' land without consent or proper compensation. Under the operation, many victims and petitioners have been coming to the US and staging regular rallies and exhibitions in front of the UN headquarters since 2012, with banners and photos, telling the world what happened to their properties, how they were illegally detained and tortured when seeking justice against the local authorities benefiting from land sales (Boxun News, 2013a). As if to apply the ancient Chinese petition method of blocking the emperor's carriage to plead him to correct the unlawful acts by local officials, two Sparrow petitioners blocked Xi Jinping's motorcade on 25 September 2015, when the visiting Chinese president was heading to the State Department. The two women rushed through police lines, ran towards the motorcade and threw themselves in front of two limousines, one believed to be Xi's. Under the broad public glare, a Chinese official, believed to be Xi's secretary or aide, took petition letters from the adventurous protesters. The videos of this saga went viral on You Tube (Initiatives for China, 2015). 
Street performance art is also experiemented in other protest rallies in recent years. In the annual rallies to commemorate the June 4 event, performances showing tanks crushing students have been staged. For 28 days in September 2013, in Times Square, Wang Juntao was sitting in a makeshift cage with moveable bars to mark the 10th year of Wang Bingzhang's imprisonment back in China. Dissidents have chosen the Oskar Awards ceremony day to present their own Oskar Award for Chinese Freedom and Human Rights. They staged the show at a spot as close as possible to the official ceremony in order to attract attention, and the award object is a replica of the original Oscar statuette except with shackles around it (Boxun News, 2014).

\section{Rejuvenating Solidarity with Other Societies of Greater China}

As discussed earlier, Taiwan's role in OCDM has undergone a metmophasis, from ardent support to detachment. However, while the state of Taiwan has been washing its hands off the mainland dissidents, the latter have come to realize the potentials of the society in Taiwan. Wang Dan started to live and work in Taiwan as a teacher at various universities since 2010, joining Wuer Kaxi, another prominent Tiananmen student leader who settled on the island in the mid-1990s. Even though it has been challenging for these activists to manoeuvre through Taiwan's chronic partisan quagmire, they have found ready platforms in the recent waves of the thousands of mainland students enrolling in Taiwanese universities. If teacher Wang is an ideal person to pass the knowledge of Tiananmen to those mainland students who are also witnessing democracy in action in a Chinese society, political fugitive Wuer Kaixi's campaign for the 2016 legislative elections as an independent candidate may serve as a living democratic demonstration to the mainlanders.

More significantly, from 2011-12, the maturing civil society in Taiwan has started to pick up what the state and main political parties have left out in terms of solidarity with OCDM. Some social activists and Democratic Progressive Party legislators rooted in social movements started to argue that care for democracy and human rights in China does not have to hinge on one's attitude towards "one China" unification. Having signed and nationalised international laws on human rights, Taiwan should support China's democratisation from the standpoint of universal values. In addition, activists and students perceive China as a looming challenge to Taiwan's own human rights standards as well as a security threat. If political restrictions and censorship on Taiwanese citizens visiting or living in China is no longer news, then China's penetration in Taiwan's society and economy, a result of the Ma administration's black-box dealing with the mainland, is seen to also erode freedom of speech and rights conditions on the island itself. The Sunflower Student Movement of March-April 2014, when hundreds of university students and other civic activists occupied the chamber of the Legislative Yuan to protest the Ma administration's secretive trade deals with Beijing, showed that China could no longer be avoided even for those elements of the Taiwanese society who are least attached to the historical "one China" sentiment. Thus supporting China's democratisation is to care for the survival of Taiwan's own democracy. Instead of treating the Chinese dissidents as anti-communist warriors or avoiding them just because of their lack of support for Taiwan independence, they should be assisted as fellow travellers for the shared universal values and Taiwan's political well being, and those dissidents jailed in China should be dealt with simply as prisoners of conscience as defined by international laws, from a perspective free of historical and cultural obsession with China. It was with such new sentiment that a Taiwan Association for China Human Rights (TACHR) was founded in May 2011 (Yang, 2015), and the well-established Taiwan Association for Human Rights (TAHR), which avoided China-related cases all along, has also started to campaign for rights conditions in China (Wei, C. F., 2015). This demonstrates to the world that the Taiwanese people, having achieved democratization themselves, still care about the lack of political freedom in other countries, just as activists in the West assisted democracy fighters in Taiwan, including political exiles from the island, during the years of the Kuomintang's authoritarian regime.

This emerging sentiment has opened a new window of opportunity for OCDM. Mainland dissidents have started to proactively tap Taiwan's civil society as a new resource. As a result of their joint campaigns with TACHR and TAHR, resolutions have been adopted in the Legislative Yuan expressing concerns with the Chinese prisoners of conscience. Initiatives for China chose Taipei as the site for itsannual Interethnic Interfaith Leadership Conference in April 2014, when the Sunflower Student Movement was unfolding. The Taiwanese activists were invited from the front line to exchange ideas with the rights defenders fetched from the mainland and provide first-hand training of the methods used in peaceful social movements including how to handle the police (Chen, 2015). Though some tactics taught by the Taiwanese activists were not totally applicable across 
the strait, capitalizing on the island's advanced civil society to help the mainland activists is a creative approach of OCDM, at a time when generous ideological and financial support from any Taiwanese governemnt seems distant history. Another encouraging development is that, initiated by Wang Dan but systematically organized by TACHR and a range of Taiwanese student and social groups, an annual Tiananmen memorial service has been held in Taipei's Freedom Square since 2011. The author's personal observation suggests that over the years the attendants increased from a few hundreds to close to a thousand, easily the largest overseas Tiananmen memorial rally second only to the annual June 4 vigils held in Hong Kong's Victoria Park.

On the other hand, the continuing memorial service in Hong Kong fails to conceal the former colony's declining role in lending direct support for the mainland's democratization. The 1997 hand over meant that Hong Kong's position as the Chinese political exiles' nearest operational base to the mainland since the late Qing dynasty was largely lost. Furthermore, despite the existence of a small network of hard-core OCDM supporters, the recent decade has witnessed the rise of a strong localist political consciousness, particularly among the young generations who no longer have the sort of proclivity to identify with political development on the mainland like their parents. Most of them are more interested in resisting Beijing'serosion of political freedom and obstruction of full democratization in Hong Kong, in order to maintain its international and pluralistic identity.

However, the mainland dissidents' perceptions of Hong Kong have recently changed, due to a series of mass sit-in street protests there urging genuine universal suffrage, whereby all Hong Kong residents would have the right to vote for the post of the Chief Executive, the city's top official. In particular, during SeptemberDecember 2014, in what became known as the Umbrella Movement, protestors took over downtown Hong Kong and held it for seventy-nine days. The mainland dissidents in exile profoundly valued Hong Kong's political struggle for its demonstration effect on the mainland and launched global campaigns to support it. Though few dissidents could manage to sneak into Hong Kong to join the Umbrella Movement, joint rallies were held with Hong Kong expatriates, and ideas and lessons were exchanged intensely between Hong Kong student leaders and the former Tiananmen activists. A milestonein solidarity was that the mainland dissidents used the We The People petition mechanism of the White House, whereby a petition with no less than 100,000 signatures would secure an official response from the US administration. Framing their campaign as a struggle to prevent a second Tiananmen massacre in Hong Kong, dissident groups gathered 197,001 signatures, thus the Obama administration must make a clear statement about the ongoing Umbrella Movement. Among other points in support of "the aspirations of the Hong Kong people", the official response from the White House made it clear that "We believe that the legitimacy of the Chief Executive will be greatly enhanced if the Basic Law's ultimate aim of selection of the Chief Executive by universal suffrage is fulfilled and if the election provides the people of Hong Kong a genuine choice of candidates representative of the voters' will” (White House, 2014).

\section{Conclusion: OCDM towards the Normal?}

In China's ever expanding global politico-diplomatic shadow, and living with the Western world's accommodation with Beijing, the question of whither the overseas Chinese democracy movement goes has been asked by both its detractors and supporters. The OCDM has long been ruled out as a community with a major direct role to play in China's democratization or its host states' policies towards China. However, transnational activism has developed new dynamics over the recent decade. Despite the continuing intra-movement tension and controversies, the exile community has become more flexible and adaptable in both strategic direction and tactical approaches, with more energy spent on trying to intervene and support new social contention in China, establish specialized campaign organizations, experiment with new models of organizational development, influence domestic and international public opinions, and rejuvenate solidarity with the evolving civil societies in Taiwan and Hong Kong on the basis of shared political values more than "one China" sentiment. In conjunction, these dynamics will suggest that the Chinese political activism in exile has started to move towards pragmatism and professionalism, with more activists finding their niche roles to make the movement survive and to develop as well as strengthening its impact in the sphere of civic politics. The OCDM is now neither a spark nor a spreading prairie fire, but may have the potential to function as a kindling material under the right broad circumstances beyond the exiles' control. In hindsight, the exciting scene in the early 1990s, when the OCDM inflated by the one-off event of Tiananmen was fighting what was widely seen as a falling party-state in China, was abnormal, 
and the current circumstance of the movement was normal or the new normal.

\section{References}

Boxun News (2013a). Petitioners Association of China Forced Eviction Visited the UN to Defend Rights. (In Chinese) http://news.boxun.com/news/gb/yuanqing/2013/04/201304121323.shtml\#.VmWbvWOqlm5

Boxun News (2013b). Workers Leader Han Dongfang on Chinese Union Movement at Duke University. (In Chinese) http://news.boxun.com/news/gb/intl/2013/04/201304281117.shtml\#.VlE7fWOqlm4

Boxun News (2014). Shinning on the Star Track: The First Oskar Award for Chinese Freedom and Human Rights. (In Chinese) http://news.boxun.com/news/gb/intl/2014/03/201403031151.shtml\#.UxSC5oXEKSo

Chan, R. P. (2013). Overseas Democracy Movement Must Swallow Its Own Bitter Pills. Huanqiu Shibao. (In Chinese) http://opinion.dwnews.com/news/2013-08-14/59309687.html

Chen, J. (2012). Transnational Civil Society in China: Intrusion and Impact. London: Edward Elgar.

Chen, J. (2014). The Overseas Chinese Democracy Movement after Thirty Years: New Trends at Low Tide. Asian Survey, 54, 445-470. http://dx.doi.org/10.1525/as.2014.54.3.445

Chen, W. J. (2013). Global Times Knows Nothing about Democracy Movement’s Great Ambition. (In Chinese) http://news.boxun.com/news/gb/pubvp/2013/08/201308180817.shtml\#.UhIqWT-6W1c

Chen, W. J. (2015). Personal Interview. April 2015, Sydney.

CK (2015a). Humanitarian China and China Change Joint Donations to Help Gao Yu. (In Chinese) http://www.rfa.org/mandarin/yataibaodao/meiti/ck-04292015102858.html

CK (2015b). Democracy Theoretician Larry Diamond Teaches at the Tiananmen University of Democracy. (In Chinese) http://www.rfa.org/mandarin/yataibaodao/renquanfazhi/ck-02052015102619.html

Fitzgerald, J. (2014). Why Values Matter in Australia’s Relations with China. 13 June. http://www.theasanforum.org/why-values-matter-in-australias-relations-with-china/

Friends of FDC (2014-15). A Google Discussion Group, Various Postings.

Goddeeris, I. (2007). The Temptation of Legitimacy: ExilePolitics from a Comparative Perspective. Contemporary European History, 16, 395-405. http://dx.doi.org/10.1017/S0960777307003992

He, B. G. (2013). Working with China to Promote Democracy. The Washington Quarterly, 36, 37-53. http://dx.doi.org/10.1080/0163660X.2013.751649

He, R. (2014). Tiananmen Exiles: Voices of the Struggle for Democracy in China. New York: Palgrave Macmillan. http://dx.doi.org/10.1057/9781137438324

Hiatt, F. (2013a). Five Chinese Daughters Speak Up for Their Fathers. The Washington Post, 6 December. http://www.washingtonpost.com/opinions/fred-hiatt-five-chinese-daughters-speak-up-for-their-fathers/2013/12/05/195b67 04-5df1-11e3-be07-006c776266ed_story.html

Hiatt, F. (2013b). Nine Days. Washington DC: Delacorte Press.

Holmes, O. (2015). UN condemns Thai Repatriation of Chinese Dissidents. The Guardian, 17 November. http://www.theguardian.com/world/2015/nov/17/un-condemns-thailand-repatriation-chinese-dissidents

Initiatives for China (2015). Two Sparrows Blocked Xi Jinping’s Motorcade. Press Release, 17 November.

Keck, M. E., \& Sikkink, K. (1998). Activists beyond Borders: Advocacy Networks in International Politics. London: Cornell University Press.

Qi, J. Z. (2010). The Black Wall: The True Story of Father \& Daughter. Melbourne: Book Pal.

Qi, J. Z. (2011). Red Dog: My Days in China. Taipei: Yunchen Culture. (In Chinese)

Qi, J. Z. (2014). Survivors inside the Black Walls. Taipei: Xinrui Wenchuang Publisher. (In Chinese)

Shambaugh, D. (2015). China’s Soft Power Push: The Search for Respect. Foreign Affairs, 94.

https://www.foreignaffairs.com/articles/china/2015-06-16/china-s-soft-power-push

Sheng, X. (2013). Personal Email, September.

Sun, B. Q. (2011). A Woman Prisonerin Shanghai. Hong Kong: Wuqi Society Publisher. (In Chinese)

Sun, L.Y. (2009). Walking through the Icy Mountain. Hong Kong: Wuqi Society Publisher. (In Chinese)

Sun, L.Y. (2015). Personal Interview, Sydney, April.

Wang, C. (2011). Lessons of Twenty Years of Overseas Democracy Movement. (In Chinese) 
http://www.peacehall.com/news/gb/pubvp/2011/06/201106052302.shtml

Wang, D. (2012). Wang Dan Mémoire: From 4 June to Exile. Taipei: China Times Press. (In Chinese)

Wang, J. T. (2014). Personal Interview, New York, December.

Wang, J. T. (2015). Personal Email, July.

Wapner, P. (1996). Environmental Activism and World Civic Politics. Albany, NY: State University of New York Press.

Wei Jingsheng Foundation (2015). Wei Jingsheng Foundation News and Article Release. A891-W573. 27.

Wei, C. F. (2015). Former President of TAHR, Personal Interview, Taipei, May.

Wei, J. S. (2014). Personal Interview, Washington DC, December.

Wei, J. S. (2015). Personal Email, October.

White House (2014). Response to We the People Petition on the Protests in Hong Kong.

https://petitions.whitehouse.gov/petition/support-hong-kong-democracy-and-prevent-second-tiananmen-massacre-hong-ko ng

Xi, J. P. (2015). Consolidate and Develop the Broadest Patriotic United Front. (In Chinese)

http://news.xinhuanet.com/politics/2015-05/20/c_1115351358.htm

Xue, W. (2013). Personal Email, September.

Xue, W. (2015). Personal Email, October.

Yan, J. Q. (2008). Personal Interview, New York, July.

Yan, J. Q. (2010). Thousand Years’ Imprisonment for China Democracy Party. 23 August. (In Chinese) http://blog.boxun.com/hero/201008/yanjiaqi99/2_1.shtml

Yang, G. B. (2009). The Power of the Internet in China: Citizen Activism Online. New York: Columbia University Press.

Yang, J. L. (2013). China Hasn’t Earned a Spot on Human Rights Council. The Washington Post, 2 November. http://www.washingtonpost.com/opinions/yang-jianli-china-hasnt-earned-a-spot-on-human-rights-council/2013/11/01/a2e 444da-431d-11e3-a751-f032898f2dbc story.html

Yang, S. H. (2015). President of TACHR, Personal Interview, Taipei, May.

Zhou, Y. C. (2010). Survey of Chinese Political Movement in Exile over the Past Twenty Years. Beijing Spring, 209, 76-89. (In Chinese) 